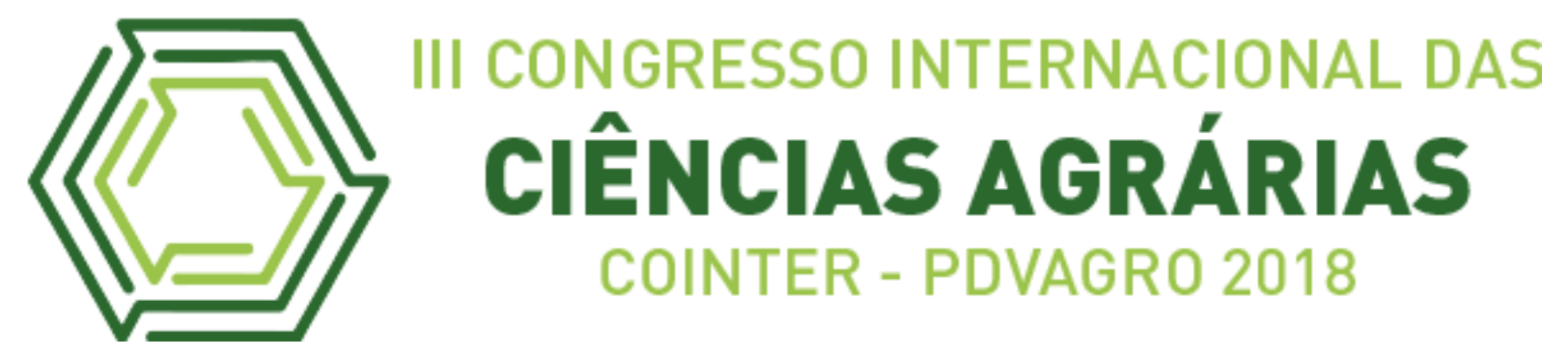

\title{
IMPORTÂNCIA DO TRABALHO DE MELHORAMENTO VEGETAL PARA A PRODUÇÃO AGRÍCOLA
}

\section{IMPORTANCE OF THE WORK OF PLANT BREEDING FOR AGRICULTURAL PRODUCTION}

Apresentação: Relato de Experiência

José Marques dos Santos ${ }^{1}$; Maciel Alves Tavares ${ }^{2}$; Elias Inácio da Silva ${ }^{3}$

DOI: https://doi.org/10.31692/2526-7701.IIICOINTERPDVAGRO.2018.00742

\section{Introdução}

O presente trabalho tem por objetivo expor a experiência vivenciada por estudantes do Bacharelado em Agronomia do IFPE campus Vitória de Santo Antão na visita técnica realizada à Estação Experimental do Instituto Agronômico de Pernambuco - IPA do Município de Belém do São Francisco que fica localizada na Ilha do Estreito.

Tal visita teve por objetivo aperfeiçoar a prática profissional dos estudantes tornandoos futuros profissionais qualificados e capazes de atuar na sua área de maneira segura e competente.

\section{Relato de Experiência}

No dia 15 de maio de 2018 estudantes do Bacharelado em Agronomia do IFPE campus Vitória de Santo Antão juntamente com os Professores: Dr. Alberto Belo Esteves Filho, Dr. Adônis Queiroz Mendes, Dr. José Emilson Macedo Ferreira e Dr. Elias Inácio da Silva vivenciaram a experiência de visitar a Estação Experimental do Instituto Agronômico de Pernambuco - IPA do Município de Belém do São Francisco que fica localizada na Ilha do Estreito. Ao chegar à Estação Experimental os estudantes junto com os professores foram recebidos pelo Técnico Agrícola Edilson de Souza Santos que os levou até a sede da Estação onde encontraram os especialistas em melhoramento genético Dr. Jonas Araújo Candeia e a

\footnotetext{
${ }^{1}$ Bacharelado em Agronomia, IFPE, josemarquesdossantos87@gmail.com

2 Bacharelado em Agronomia, IFPE, macieltavares15@gmail.com

${ }^{3}$ Professor Doutor de Agronomia, IFPE, elinasi.silva@gmail.com
} 
Dra $^{\text {a }}$ Mina Karasawa que os explicaram sobre os trabalhos realizados por eles no melhoramento vegetal naquela Estação do IPA.

"O melhoramento de plantas é a forma mais ecologicamente responsável de se aumentar a produção de alimentos com a adaptação da planta ao ambiente e não do ambiente à planta.” (BORÉM; MIRANDA, 2013, p. 29). Sabendo-se disso, na Estação Experimental do IPA de Belém do São Francisco são realizados trabalhos de melhoramento vegetal com várias culturas, como milho e feijão, mas as principais culturas trabalhadas são a cebola e o tomate por terem uma grande importância para a economia da região. Na região, a cebola se destaca, principalmente, por sua colheita no segundo semestre, período da entressafra de outras regiões produtoras, com isso consegue-se produzir em um período em que os preços estão mais atrativos para os produtores.

Várias cultivares de sucesso já foram lançadas pelo IPA, como por exemplo, as cultivares de cebola IPA 11 e IPA 12 que são cebolas branca e roxa, respectivamente, e obtiveram grande aceitação pelo mercado produtor e consumidor. Atualmente, existem trabalhos sendo realizados para lançamento de mais duas cultivares de cebolas: a Brisa Verão e a Tropicana. Vale destacar também que esta Estação do IPA produz sementes de suas cultivares laçadas para a comercialização, e que são vendidas para todo o Brasil para serem cultivadas.

Imagem 1: Campo Experimental de Cebolas. Fonte: Própria.

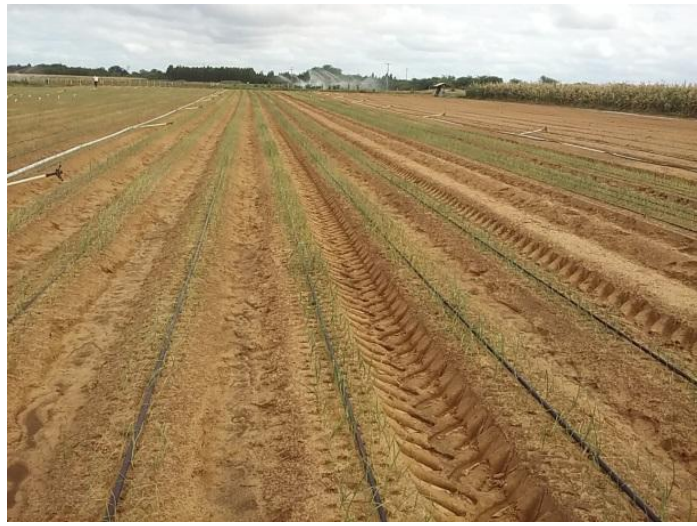

Imagem 2: Estudantes e Professores observando as explicações dos Melhoristas. Fonte: Própria.

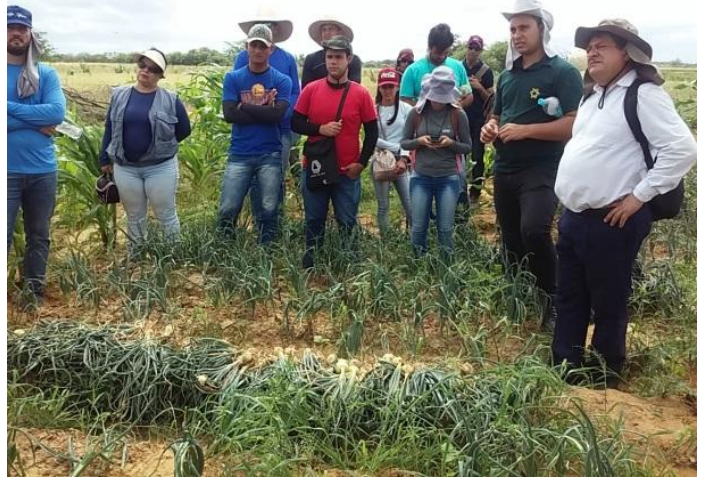

\section{Considerações}

Ao final da visita os estudantes conseguiram o aprimoramento de seus conhecimentos a partir da constatação das técnicas e processos realizados pelos especialistas do IPA nas 
atividades desempenhadas por estes para alcançar resultados positivos nos processos de melhoramento das espécies de importância agronômica.

\section{Referências}

Bases Físicas. IPA. Disponível em: http://www.ipa.br/ipa_base.php. Acesso em: 10 de outubro de 2018.

BORÉM, Aluízio; MIRANDA, Glauco V.. Melhoramento de Plantas. 6. ed. rev. e ampl. Viçosa, MG: Ed. UFV, 2013. 523 p. 